\title{
PROSPEK PRODUKSI DAN PEMASARAN BERAS PANDANWANGI MURNI DI WILAYAH PEMASARAN KABUPATEN CIANJUR
}

\author{
E. Lisarini ${ }^{1 \mathrm{a}}$ dan H. Mahdi ${ }^{1}$ \\ ${ }^{1}$ Dosen Universitas Suryakancana Cianjur \\ Jl. Pasir Gede Raya, Bojongherang, Cianjur, Jawa Barat, 43216 \\ ${ }^{a}$ Korespondensi: Endah Lisarini, E-mail: endahlisarini@yahoo.com
}

\begin{abstract}
The level of rice production and consumption at the national, provincial and district levels always varies from a number of different sources. Based on field observations in 2018 in the area of Geographical Indication of Pandanwangi Cianjur rice, the condition of the level of production and consumption of rice has fluctuated. This is what underlies a study of the prospects for pure rice production and marketing, especially Pandanwangi in Cianjur. This research was conducted to examine: 1) opportunities for developing Pandanwangi rice production in the area of Geographical Indications; 2) prospects for marketing Pandanwangi rice in the future. Response data regarding the level of prospects and the magnitude of the obstacles to the development of production and marketing of Pandanwangi rice were obtained from 5 Pandanwangi rice farmers and 3 rice shops in Cianjur. The number of respondents in this study was limited because the number of farmers who continued to plant Pandanwangi in the past two years was small and not all rice shops sold pure Pandanwangi rice Cianjur. Samples were taken by non-probability purposive sampling technique from the population of farmers producing and retailing rice in the marketing area of Cianjur rice. To answer the first research objective, which was to determine the level of opportunities and barriers to the development of Pandanwangi rice production, the classifications of the level of prospects and obstacles were carried out. The analysis and discussion were carried out in a quantitative descriptive manner. The same method of analysis was also carried out to answer the second research objective, namely the prospects and barriers to marketing pure Pandanwangi rice in Cianjur. The results showed that: 1) The level of prospects and barriers to pure Pandanwangi rice production in Cianjur, respectively in the prospect category and there were enough obstacles. The average score of respondents' responses is 4.08 and 3.28 on a scale of 1 - 4. 2) The level of prospects and barriers to marketing pure Pandanwangi rice Cianjur, each of them is very prospect and there are enough obstacles with an average score of 4.24 and 3.39 (scale 1-4)
\end{abstract}

Key words : The Prospects, Obstacles, Production, Marketing, Rice Of Pandanwangi

\begin{abstract}
ABSTRAK
Tingkat produksi dan konsumsi beras baik di tingkat nasional, provinsi maupun kabupaten menunjukkan angka yang beragam dari sejumlah sumber yang berbeda. Berdasarkan observasi lapang tahun 2018 di daerah Indikasi Geografis Padi Pandanwangi Cianjur, kondisi tingkat produksi dan konsumsi beras mengalami fluktuasi. Hal ini yang mendasari dilakukan kajian mengenai prospek produksi dan pemasaran beras khususnya Pandanwangi murni di Cianjur. Penelitian ini dilakukan untuk mengkaji: 1) peluang pengembangan produksi padi Pandanwangi di daerah Indikasi Geografis, 2) prospek pemasaran beras Pandanwangi. Data tanggapan
\end{abstract}


mengenai tingkat prospek dan besarnya hambatan pengembangan produksi dan pemasaran beras Pandanwangi diperoleh dari 5 petani dan 3 toko beras di Cianjur. Jumlah responden terbatas disebabkan sedikitnya jumlah petani yang terus menanam Pandanwangi hingga dua tahun terakhir ini, dan tidak semua toko beras menjual beras Pandanwangi murni Cianjur. Sampel diambil dengan teknik non probability purposive sampling dari populasi petani produsen dan pengecer beras yang ada di wilayah pemasaran beras Cianjur. Untuk menjawab tujuan penelitian pertama, dilakukan pengkategorian kelas tingkat prospek dan hambatan. Analisis dilakukan secara deskriptif kuantitatif. Metode analisis yang sama juga dilakukan untuk menjawab tujuan penelitian kedua. Hasil penelitian menunjukkan bahwa: 1) Tingkat prospek dan hambatan produksi padi Pandanwangi murni Cianjur, berturut-turut pada kategori prospek dan cukup ada hambatan. Nilai skor rata-rata tanggapan responden berturut-turut sebesar 4.08 dan 3.28 pada skala 1 - 4. 2) Tingkat prospek dan hambatan pemasaran beras Pandanwangi murni Cianjur, masing-masing adalah sangat prospek dan cukup ada hambatan dengan nilai skor rata-rata sebesar 4.24 dan 3.39 (skala 1- 4).

Kata kunci : Prospek, Hambatan, Produksi, Pemasaran, Beras Pandanwangi

\section{PENDAHULUAN}

Bahan pangan merupakan salah satu komoditas strategis sehingga banyak pihak yang berkepentingan dengan produk ini. Meskipun sejumlah sumber memberitakan tingkat produksi dan konsumsi beras yang beragam, namun menurut Badan Pusat Statistik (BPS) tahun 2018, secara nasional luas panen padi bulan Januari-Desember 2018 mencapai 10,9 juta hektar, dan produksi total padi sebesar 56,54 juta ton gabah kering giling atau setara dengan 32,42 juta ton beras. Angka konsumsi beras tahun 2017 mencapai 29,5 juta ton. Potensi produksi padi Jawa Barat tahun 2018 mencapai 9,54 juta ton atau 4,77 juta ton beras. Menurut BPS (2018), dengan jumlah penduduk Jawa Barat sebesar 48,68 juta dan konsumsi beras per kapita per tahun rata-rata 130 kg (Saragih diacu dalam Purwono 2013; Mohanty diacu dalam David 2015), maka perkiraan konsumsi total beras di Jawa Barat mencapai 6.3 juta ton. Keadaan ini merupakan peluang besar bagi petani produsen beras untuk memenuhi kekurangan konsumsi tersebut, tidak terkecuali Cianjur yang merupakan sentra produksi beras Jawa Barat.
Luas sawah yang ditanami Pandanwangi di Daerah Indikasi Goegrafis Cianjur, hanya $1.861 \mathrm{Ha}$, dan luas sawah terbesar berada di Kecamatan Warungkondang seluas $760 \mathrm{Ha}$, dengan produktivitas sebesar 5 - 6 ton beras dari dua kali musim panen. Dengan demikian potensi produksi beras di Kecamatan Warungkondang mencapai 3.800 - 4.560 ton (Dinas Pertanian Tanaman Pangan dan Hortikultura Kab. Cianjur, 2017).

Berbagai upaya untuk meningkatkan produksi beras dan perbaikan sistem pemasarannya terus dilakukan oleh semua pihak terkait termasuk pemerintah. Sejumlah kebijakan pemerintah yang mendukung kemandirian pangan (UU No.18, 2012; Perda Jabar No.4, 2012), berhubungan dengan pengaturan distribusi beras dan penetapan harga. Penelitian ini dilakukan untuk menggali lebih dalam masalah produksi dan pemasaran beras Pandanwangi murni Ciajur. Penelitian ini bertujuan untuk mengkaji: (1) besarnya prospek pengembangan produksi padi pandanwangi di wilayah Indikasi Geografis; 2) prospek pemasaran beras Pandawangi Cianjur. Hasil penelitian ini diharapkan dapat lebih mengenalkan kepada masyarakat konsumen 
mengenai beras Pandanwangi, terutaman dari segi pengembangan produksi dan prospek pemasarannya, dan ikut berkontribusi dalam kebijakan Pemerintah Daerah Cianjur dalam mendukung pengembangan dan pelestarian padi Pandanwangi Ciajur.

\section{BAHAN DAN METODE}

\section{Kerangka Teoritis}

Beras sebagai produk siap konsumsi ternyata harganya sangat jauh berbeda dengan produk asalnya yaitu gabah atau malai. Hasil observasi lapang di wilayah pemasaran Cianjur tahun 2018, memberikan informasi harga gabah/ malai padi Pandanwangi sebesar Rp. 6.000 per kilogram, sementara harga berasnya per kilogram berkisar antara Rp. 20.000 - Rp. 35.000. harga ini sangat dipengaruhi oleh teknik budidaya yang dilakukan apakah organik atau konvensional. Keadaan demikian dikenal sebagai pasar gabah/malai bersifat asimetris terhadap pasar beras. Terjadinya disparitas harga gabah/malai dengan harga beras yang cukup besar inilah yang disebut sebagai pasar asimetris (Fauziah 2016).

Selama ini harga beras Pandanwangi termasuk ke dalam kelas mutu beras khusus yang tidak diatur oleh pemerintah (Peraturan Menteri Pertanian Nomor 31/PERMENTAN, 2017). Pandanwangi merupakan salah satu jenis beras di Indonesia yang sudah mendapatkan Sertifikat Indikasi Geografis (SIG) dari Kementerian Hukum dan HAM RI tahun 2014. Pandanwangi merupakan beras lokal Cianjur yang sudah populer akan aroma khas dan kepulenannya. Karakteristik botani Pandanwangi yang membedakannya dengan tanaman padi lainnya adalah tinggi tanaman yang mencapai $150 \mathrm{~cm}$ dan berumur panjang sekira 155 hari serta nilai jual yang lebih tinggi dibandingkan dengan beras Cianjur lainnya (Dinas Pertanian Kabupaten Cianjur, 2009; MP3C, 2015).

Kekhususan inilah yang menjadikan harga beras Pandanwangi relatif tinggi dibandingkan dengan beras khusus lainnya. Hal ini menjadikannya sebagai peluang usaha. Peluang usaha merupakan kreativitas dan inovasi menciptakan nilai tambah dengan melibatkan individu atau kelompok, memanfaatkan sumberdaya yang ada guna meraih kesempatan dan dimanfaatkan sekarang dan masa yang akan datang (Hadiyati 2011; Damayanti 2013). Peluang bisnis perberasan masih cukup besar dengan adanya kondisi komsumsi beras masih di atas produksi beras seperti yang sudah disebut di atas. Meskipun secara kumulatif tingkat konsumsi pangan khususnya beras lebih besar daripada tingkat produksinya, akan tetapi tingkat konsumsi yang fluktuatif dalam suatu periode akan mempengaruhi tingkat produksi dalam suatu periode yang sama.

Tidak hanya tingkat konsumsi saja sebagai peluang yang mempengaruhi tingkat produksi, namun ada sejumlah kendala / hambatan yang juga berpengaruh pada produksi. Kendala utama produksi padi saat ini ialah penurunan luas baku lahan sawah akibat alih fungsi lahan dan kejenuhan teknologi. Kedua masalah inilah yang mestinya menjadi agenda utama revitalisasi usahatani padi (Yudhistira 2013). Selain itu masih terdapat kendala bisnis perberasan lainnya yaitu masalah distribusi atau pemasarannya. Komoditas beras harus melalui banyak titik dalam saluran distribusi hingga sampai kepada konsumen yang mengakibatkan tingginya harga di tingkat konsumen dan menjelaskan mengapa banyak petani ternyata tidak menikmati harga yang tinggi tersebut (Restapiadi dalam Sihombing 2018). 


\section{Metode Penelitian}

Penelitian ini dilaksanakan di sentra produksi dan wilayah pemasaran beras Pandanwangi di Kabupaten Cianjur. Dasar penentuan lokasi penelitian didasarkan pada tujuh kecamatan di Cianjur yang merupakan daerah Indikasi Geografis Pandanwangi yaitu Kecamatan Warungkondang, Campaka, Cibeber, Cilaku, Gekbrong, Cianjur dan Cugenang (MP3C 2015) dan sekaligus sebagai wilayah pemasaran beras Pandanwangi. Populasi dalam penelitian ini adalah para petani sebagai produsen beras Pandanwangi dan pengusaha yang menjual beras Pandanwangi murni Cianjur. Karena jumlah petani penanam sekaligus penggiling malai Pandanwangi yang terus menerus dalam dua tahun terakhir ini tidak diketahui secara pasti, demikian pula dengan jumlah pedagang beras Pandanwangi murni, maka dilakukan sampling dengan teknik non probability purpossive sampling.

Sampel yang diambil sebanyak 5 orang petani penanam sekaligus penggiling dan tiga penjual beras Pandanwangi murni. Pada penelitian ini, variabel yang dikaji ditunjukkan pada Lampiran 1 meliputi: prospek produksi dan pemasaran beras Pandanwangi. Variabel penelitian tidak dikelompokkan ke dalam variabel bebas dan variabel tergantung, karena hanya dikaji tingkat peluang atau prospek dan tingkat kendala atau hambatan dalam produksi dan pemasaran beras Pandanwangi murni
Cianjur. Tingkat prospek produksi diukur melalui indikator : Adanya insentif bagi petani penanam Pandanwangi, banyaknya kebijakan pemda mengurangi alih fungsi lahan pertanian ke non pertanian, kondisi geografis alam yang sesuai dengan kebutuhan hidup Pandanwangi, Pandanwangi sebagai kearifan lokal Cianjur yang perlu dilestarikan.

Tingkat kendala atau hambatan produksi diukur melalui indikator : banyaknya petani yang malas menanam Pandanwangi, banyaknya alih fungsi lahan pertanian ke non pertanian, iklim dan cuaca yang tidak menentu, bertambahnya varietas unggul baru yang lebih mudah diproduksi. Tingkat prospek pemasaran beras Pandanwangi diukur melalui indikator : adanya peluang ekspor, adanya kerjasama dengan distributor dan pengecer, bertambahnya peminat beras Pandanwangi, berkembangnya iklan dalam pemasaran beras Pandanwangi. Indikator tingkat kendala pemasaran diukur dengan: menurunnya pasokan beras, harga beras Pandanwangi yang relatif tinggi, masih ditemui beras Pandanwangi yang tidak murni, masyarakat konsumen masih belum mengenal beras Pandanwangi dengan baik, harga beras varietas unggul yang lebih murah. Tanggapan responden diukur dengan skala Likert berperingkat atau ordinal dari skala 1 sampai 5 dengan kategori seperti pada Tabel 1 .

Tabel 1. Kategori tanggapan responden dengan peringkat skala Likert

\begin{tabular}{cll}
\hline \multirow{2}{*}{ Nilai Interval } & \multicolumn{2}{c}{ Kategori } \\
\cline { 2 - 3 } $1,00-1,80$ & Prospek & \multicolumn{1}{c}{ Hambatan } \\
$1,81-2,60$ & Tidak Prospek & Sangat tidak menghambat \\
$2,61-3,40$ & Cukup & Tidak menghambat \\
$3,41-4,20$ & Prospek & Menghambat \\
$4,21-5,00$ & Sangat Prospek & Sangat menghambat \\
\hline
\end{tabular}


Untuk menjawab tujuan penelitian pertama yaitu mengetahui tingkat prospek dan kendala produksi beras Pandanwangi, dilakukan pengkategorian kelas tingkat prospek dan kendala produksi. Terdapat lima kelas tingkat prospek dan kendala produksi dengan interval kelas dihitung melalui skor nilai tanggapan tertinggi yaitu 5 dikurangi skor nilai tanggapan terendah yaitu 1 . Selanjutnya nilai selisih tersebut dibagi dengan jumlah kelas yaitu lima. Hasil penghitungan diperoleh nilai sebesar 0.8 yang merupakan interval kelas seperti pada Tabel 1.

Untuk menjawab tujuan penelitian ke dua, dilakukan metode yang sama dengan tujuan penelitian ke satu hanya ditujukan untuk mengkaji tingkat prospek dan kendala pemasaran beras Pandanwangi

\section{HASIL DAN PEMBAHASAN}

Pengumpulan data kuantitatif dilakukan terhadap 8 responden yang terdiri atas 3 orang petani sekaligus penggiling beras Pandanwangi dan 5 pemilik toko beras yang menjual beras Pandanwangi murni di wilayah pemasaran Cianjur. Karakteristik responden dalam penelitian ini meliputi : jenis kelamin, usia, profesi atau stutusnya sebagai produsen atau pengecer dan lamanya berbisnis beras. Seluruh karakteristik tersebut dapat dijelaskan pada Gambar 1 dan Tabel 3 - 4 berikut ini.

\section{jenis kelamin}

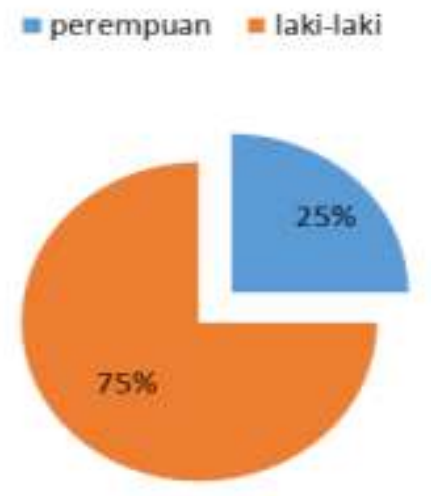

\section{usia}

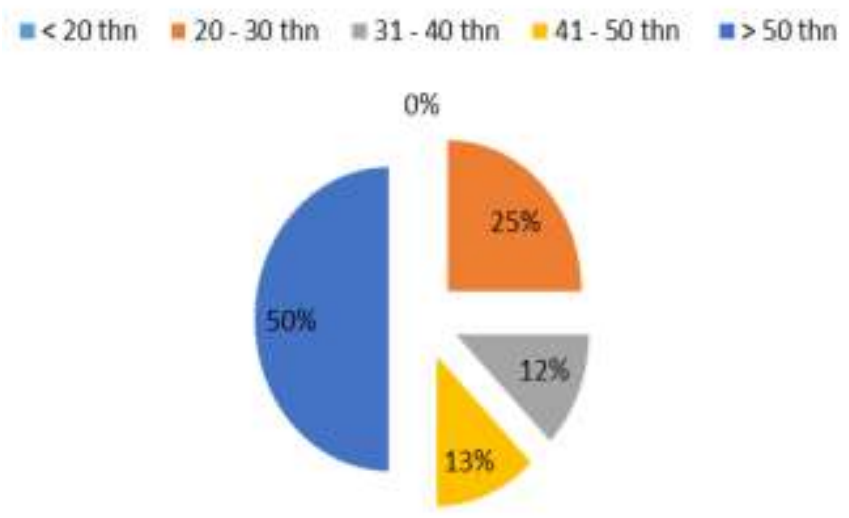

Gambar 1. Persentasee jenis kelamin dan komposisi usia responden

Tabel 2. Lama Usaha Perberasan Yang Dijalani Responden di Kabupaten Cianjur, 2018

\begin{tabular}{cccc}
\hline No & Lama Usaha & Jumlah Responden (Orang) & Presentase (\%) \\
\hline 1 & $<1$ tahun & 0 & - \\
2 & 1 tahun & 1 & 12,5 \\
3 & 2 tahun & 1 & 12,5 \\
4 & 3 tahun & 0 & - \\
5 & $>3$ tahun & 6 & 75 \\
\hline 6 & Jumlah & 8 & 100 \\
\hline
\end{tabular}


Tabel 3. Status Pekerjaan Responden di Kabupaten Cianjur, 2018

\begin{tabular}{clcc}
\hline No & \multicolumn{1}{c}{ Profesi } & Jumlah Responden (Orang) & Presentase (\%) \\
\hline 1 & Petani / Produsen & 5 & 63 \\
2 & pengecer & 3 & $37 \%$ \\
\hline & Jumlah & 8 & 100 \\
\hline
\end{tabular}

Dari Gambar 1 dan Tabel 3 - 4 dapat dilihat bahwa responden yang dijadikan sumber informasi didominasi oleh pria yang berusia lebih dari 50 tahun. Dari jumlah tersebut, sebanyak $75 \%$ sudah berkecimpung di perberasan selama lebih dari 3 tahun. Sebanyak $63 \%$ adalah petani yang sekaligus sebagai penggiling atau produsen beras sedangkan sisanya berprofesi sebagai pengecer beras. Keadaan responden yang demikian menjamin didapatkannya informasi dan data yang akuntabel terkait dengan obyek dan variabel penelitian.
Untuk menjawab tujuan penelitian pertama, data tanggapan responden dianalisis secara deskriptif terlebih dahulu untuk mengetahui tanggapan rata-rata responden terhadap tingkat prospek dan kendala produksi beras. Skor rata-rata tanggapan dikategorikan ke dalam kelas kategori seperti pada Tabel 1. Secara deskriptif dapat diketahui bahwa tanggapan responden terhadap tingkat prospek dan kendala produksi Pandanwangi dapat diringkas pada Tabel 5 .

Tabel 5. Kategori Tanggapan Responden Terhadap Tingkat Prospek dan Hambatan Produksi Beras Pandanwangi di Kabupaten Cianjur, 2018

\begin{tabular}{|c|c|c|c|c|}
\hline No & Variabel Prospek Produksi & Rata-rata & Nilai Interval & Kategori \\
\hline \multicolumn{5}{|c|}{ Prospek } \\
\hline 1 & $\begin{array}{l}\text { Adanya insentif bagi petani penanam } \\
\text { Pandanwangi }\end{array}$ & 4,80 & $4,21-5$ & Sangat prospek \\
\hline 2 & $\begin{array}{l}\text { Banyaknya kebijakan pemda } \\
\text { mengurangi alih fungsi lahan pertanian } \\
\text { ke non pertanian }\end{array}$ & 4,60 & $4,21-5$ & Sangat prospek \\
\hline 3 & $\begin{array}{l}\text { Kondisi geografis alam yang sesuai } \\
\text { dengan kebutuhan hidup Pandanwangi }\end{array}$ & 4,00 & $3,41-4,2$ & prospek \\
\hline 4 & $\begin{array}{l}\text { Pandanwangi sebagai kearifan lokal } \\
\text { Cianjur yang perlu dilestarikan }\end{array}$ & 3,80 & $3,41-4,2$ & prospek \\
\hline \multicolumn{2}{|c|}{ Rata-rata } & \multicolumn{2}{|r|}{4,30} & Sangat Prospek \\
\hline \multicolumn{5}{|c|}{ Hambatan } \\
\hline 1 & $\begin{array}{l}\text { Banyaknya petani yang malas menanam } \\
\text { Pandanwangi }\end{array}$ & 3,60 & $3,41-4,2$ & Menghambat \\
\hline 2 & $\begin{array}{l}\text { Banyaknya alih fungsi lahan pertanian } \\
\text { ke non pertanian }\end{array}$ & 3,55 & $3,41-4,2$ & Menghambat \\
\hline 3 & Iklim dan cuaca yang tidak menentu & 2,80 & $2,61-3,4$ & Cukup \\
\hline 4 & $\begin{array}{l}\text { Bertambahnya varietas unggul baru yang } \\
\text { lebih mudah diproduksi }\end{array}$ & 3,80 & $3,41-4,2$ & Menghambat \\
\hline \multicolumn{2}{|r|}{ Rata-rata } & \multicolumn{2}{|l|}{3,44} & Menghambat \\
\hline
\end{tabular}


Dari Tabel 5 dapat disimpulkan bahwa responden pada umumnya menyatakan sangat setuju bahwa beras Pandanwangi sangat prospek untuk terus diproduksi karena selain kondisi geografisnya yang mendukung, Pandanwangi merupakan kearifan lokal yang patut dilestarikan. Selain itu pemerintah daerah juga memberikan insentif kepada petani penanam Pandanwangi. Keadaan ini ditunjukkan dengan nilai skor rata-rata 4.30 (interval 4.2 - 5.0) kategori sangat prospek. Sementara tingkat prospek dan kendala pemasaran beras Pandanwangi ditunjukkan pada Tabel 6.

Tabel 6. Kategori Tanggapan Responden Terhadap Tingkat Prospek dan Hambatan Pemasaran Beras Pandanwangi di kabupaten Cianjur, 2018

\begin{tabular}{|c|c|c|c|c|}
\hline No & Variabel Prospek Pemasaran & Rata-rata & Nilai Interval & Kategori \\
\hline \multicolumn{5}{|c|}{ Peluang } \\
\hline 1 & Adanya peluang ekspor & 5,00 & $4,21-5$ & Sangat Prospek \\
\hline 2 & $\begin{array}{l}\text { Adanya kerjasama dengan } \\
\text { distributor dan pengecer }\end{array}$ & 5,00 & $4,21-5$ & Sangat Prospek \\
\hline 3 & $\begin{array}{l}\text { Bertambahnya peminat beras } \\
\text { Pandanwang }\end{array}$ & 4,00 & $3,41-4,2$ & Prospek \\
\hline 4 & $\begin{array}{l}\text { Berkembangnya iklan dalam } \\
\text { pemasaran beras Pandanwangi }\end{array}$ & 4,67 & $4,21-5$ & Sangat Prospek \\
\hline \multicolumn{2}{|c|}{ Rata-rata } & \multicolumn{2}{|c|}{4,67} & Sangat Prospek \\
\hline \multicolumn{5}{|c|}{ Hambatan } \\
\hline 1 & Menurunnya pasokan beras & 4,00 & $3,41-4,2$ & Menghambat \\
\hline 2 & $\begin{array}{l}\text { Harga beras Pandanwangi } \\
\text { yang relative tinggi }\end{array}$ & 2,00 & $1,81-2,6$ & $\begin{array}{l}\text { Tidak } \\
\text { Menghambat }\end{array}$ \\
\hline 3 & $\begin{array}{l}\text { Masih ditemui beras } \\
\text { Pandanwangi yang tidak murni }\end{array}$ & 3,00 & $2,61-3,4$ & Cukup \\
\hline 4 & $\begin{array}{l}\text { Masyarakat konsumen masih } \\
\text { belum mengenal beras } \\
\text { Pandanwangi dengan baik }\end{array}$ & 4,33 & $4,21-5$ & $\begin{array}{l}\text { Sangat } \\
\text { Menghambat }\end{array}$ \\
\hline 5 & $\begin{array}{l}\text { Harga beras varietas unggul } \\
\text { yang lebih murah }\end{array}$ & 3,38 & $3,41-4,2$ & Menghambat \\
\hline \multicolumn{2}{|c|}{ Rata-rata } & \multicolumn{2}{|r|}{3,4} & Cukup \\
\hline
\end{tabular}

Tabel 6 menjelaskan tanggapan responden terhadap tingkat prospek dan kendala pemasaran beras Pandanwangi. Responden menyatakan bahwa beras Pandanwangi sangat prospek dipasarkan walaupun cukup mempunyai kendala. Pendapat tersebut ditunjukkan berturut turut pada nilai skor rata-rata 4,67 (skala $1-5$ ) dan 3,4 (skala 1 - 5). Hal ini menjelaskan bahwa beras Pandanwangi sebagai salah satu beras khusus dan merupakan kearifan lokal Cianjur memang cukup diminati oleh konsumen karena karakteristiknya yang khas dan kualitasnya. Di lain pihak, karena statusnya sebagai beras khusus sehingga harga beras tidak diatur Harga Eceran Tertinggi (HET)nya oleh pemerintah. Hal ini mengakibatkan harga beras Pandanwangi relatif tinggi menurut tanggapan konsumen dibandingkan dengan beras lainnya yang 
kuualitasnya hamper sama. Hal lain yang menjadi kendala pemasaran beras Pandanwangi adalah banyaknya beras Pandanwangi tidak murni yang beredar di pasaran dengan harga lebih rendah dibandingkan dengan harga beras Pandanwangi murni. Sementara masih banyak masyarakat konsumen yang kurang mengenal.

\section{KESIMPULAN DAN IMPLIKASI KEBIJAKAN}

\section{Kesimpulan}

1. Produksi beras Pandanwangi sangat prospek atau mempunyai peluang yang besar walaupun ada hambatan produksi. Peluang produksi dapat dicapai karena faktor geografi yang mendukung dan adanya insentif pemerintah bagi para petani yang tetap membudidayakan Pandanwangi.

2. Pemasaran beras Pandanwangi mempunyai tingkat prospek yang sangat tinggi dengan adanya peluang ekspor dan masih diminati oleh konsumen walaupun masih cukup ada hambatan. Hambatan tersebut di antaranya adalah harga beras varietas unggul lainnya yang lebih murah dan konsumen belum mengenal dengan baik beras Pandanwangi murni.

\section{Implikasi Kebijakan}

1. Pemerintah daerah Cianjur dan MP3C sebaiknya bermitra dalam pengembangan dan pelestarian Pandanwangi. Pemerintah melalui Dinas Pertanian Cianjur dapat lebih erlibat dalam pembinaan dan layanan petani penanam Pandanwangi khususnya dalam penyediaan benih murni dan pengaturan lokasi serta waktu atau musim tanam.

2. Pemerintah daerah Cianjur dapat lebih terlibat dalam membantu pemasaran beras Pandanwangi dimulai dari penggalakan atau anjuran konsumsi beras Pandanwangi kepada para pegawai di jajarannya yang sudah termasuk ke dalam keluarga sejahtera III ke atas.

\section{Daftar Pustaka}

Badan Pusat Statistik. 2018. Perkiraan Produksi Padi Nasional tahun 2018. Jakarta. Indonesia.

Damayanti, L. 2013. Faktor-faktor yang Mempengaruhi Produksi, Pendapatan dan Kesempatan Kerja pada Usahatani Padi Sawah di Daerah Irigasi Parigi Moutong. Jurnal SEPA Vol. 9. No. 2 : 249 - 259.

David, F. 2015. Strategic Management. Concept and Cases. $13^{\text {th }}$ edition. Ebook. Prentice Hall, New Jersey.

Dinas Pertanian Tanaman Pangan Kabupaten Cianjur. 2009. Laporan Tahunan Kabupaten DT II. Cianjur.

Dinas Pertanian Tanaman Pangan Kabupaten Cianjur. 2017. Ciajur Pastikan Surplus Beras. Cianjur.

Fauziah, W. 2016. Informasi Asimetri Dalam Transmisi Harga Gabah dan Harga Beras. Diunduh 19 Februari 2019.

Hadiyati,E. 2011. "Kreativitas dan Inovasi Berpengaruh Terhadap

Kewirausahaan Kecil." Jurnal Manajemen Kewirausahaan. Vol.13. No.1, hal : 8 - 16 .

MP3C. 2015. Buku Persyaratan Persyaratan Permohonan Pendaftaran Indikasi Geografis Beras Pandanwangi Cianjur. Direktorat Jenderal Hak Kekayaan Intelektual. Jakarta

Peraturan Menteri Pertanian Republik Indonesia. 2017. Kelas Mutu Beras. No. 1/PERMENTAN/PP.130/8/2017. Jakarta.

Pemerintah Daerah Jawa barat. 2012. Indikator Kesejahteraan Jawa Barat. Bandung.

Purwono, J.,S. Sugyaningsih, A. Priambudi. 2013. "Analisis Tata Niaga Beras Di 
Kecamatan Rogojampi Kabupaten Banyuwangi". Jurnal $\mathrm{NeO}$-Bis. Vol.7.No.2.

Sihombing, M. 2018. Jalur Distribusi Beras Hingga Ke Konsumen. https://ekonomi.bisnis.com/read/2018 0117/99/727664/inilah-jalur-

distribusi-beras-hingga-ke-konsumen Diunduh 17 Januari 2019.

Subagyo, P. 2006. Statistik Induktif. BPFE. Yogyakarta
Sugiyono. 2011. Metode Penelitian Kuantitatif Kualitatif Dan R\&D. Alfabeta, Bandung.

Sugiyono. 2009. Memahami Penelitian Kualitatif. Alfabeta, Bandung. Undang - Undang No.18, 2012. Pangan. Presiden Republik Indonesia dengan persetujuan Dewan Perwakilan Rakyat Republik Indonesia.

Yudhistira, M. Dika. 2013. Analisis Dampak Alih Fungsi Lahan Pertanian Terhadap Ketahanan Pangan Di Kabupten Bekasi Jawa Barat (Studi Kasus Desa 


\section{Lampiran 1. Operasionalisasi Variabel Penelitian}

\begin{tabular}{|c|c|c|c|}
\hline $\begin{array}{c}\text { Variabel } \\
\text { penelitian }\end{array}$ & Konsep Variabel & Indikator & Skala \\
\hline $\begin{array}{l}\text { Prospek } \\
\text { (peluang) } \\
\text { Produksi dan } \\
\text { Pemasaran } \\
\text { Beras } \\
\text { Pandanwangi }\end{array}$ & $\begin{array}{l}\text { Peluang usaha merupakan } \\
\text { kreativitas dan inovasi } \\
\text { menciptakan nilai tambah } \\
\text { dengan melibatkan individu } \\
\text { atau kelompok, } \\
\text { memanfaatkan sumberdaya } \\
\text { yang ada guna meraih } \\
\text { kesempatan dan } \\
\text { dimanfaatkan sekarang dan } \\
\text { masa yang akan datang } \\
\text { (Zimmerer, 2008; Robbin dan } \\
\text { Coulter, 2010; Zarkasyi : } \\
\text { 2013). }\end{array}$ & $\begin{array}{l}\text { Peluang produksi } \\
\text { 1. Adanya insentif bagi petani penanam } \\
\text { Pandanwangi, } \\
\text { 2. Banyaknya kebijakan pemda } \\
\text { mengurangi alih fungsi lahan pertanian } \\
\text { ke non pertanian, } \\
\text { 3. Kondisi geografis alam yang sesuai } \\
\text { dengan kebutuhan hidup Pandanwangi, } \\
\text { 4. Pandanwangi sebagai kearifan } \\
\text { lokal Cianjur yang perlu dilestarikan }\end{array}$ & Ordinal \\
\hline $\begin{array}{l}\text { Kendala } \\
\text { (hambatan) } \\
\text { Produksi dan } \\
\text { Pemasaran } \\
\text { Beras } \\
\text { Pandanwangi }\end{array}$ & $\begin{array}{l}\text { Kendala utama produksi padi } \\
\text { saat ini ialah penurunan luas } \\
\text { baku lahan sawah akibat alih } \\
\text { fungsi lahan dan kejenuhan } \\
\text { teknologi. Kedua masalah } \\
\text { inilah yang mestinya menjadi } \\
\text { agenda utama revitalisasi } \\
\text { usahatani padi (Maulana dkk, } \\
\text { 2006) dan distribusi atau } \\
\text { pemasarannya (Restapiadi, } \\
\text { 2018). }\end{array}$ & $\begin{array}{l}\text { Kendala / hambatan produksi : } \\
\text { 1. Banyaknya petani yang malas menanam } \\
\text { Pandanwangi, } \\
\text { 2. Banyaknya alih fungsi lahan pertanian } \\
\text { ke non pertanian, } \\
\text { 3. Iklim dan cuaca yang tidak menentu, } \\
\text { 4. Bertambahnya varietas unggul baru yang } \\
\text { lebih mudah diproduksi. } \\
\text { Kendala / hambatan pemasaran : } \\
\text { 1. Menurunnya pasokan beras, } \\
\text { 2. Harga beras Pandanwangi yang relative } \\
\text { tinggi, } \\
\text { 3. Masih ditemui beras Pandanwangi yang } \\
\text { tidak murni, } \\
\text { 4. Masyarakat konsumen masih belum } \\
\text { mengenal beras Pandanwangi dengan } \\
\text { baik, } \\
\text { 5. Harga beras varietas unggul yang lebih } \\
\text { murah. }\end{array}$ & Ordinal \\
\hline
\end{tabular}

